\title{
Uluslararası Örgütlerin Devlet-İçi Çatışmalara Başarısız Müdahalelerinin Nedenleri
}

\author{
Reasons Behind Failed Interventions of International \\ Organizations in Intra-State Conflicts
}

\section{Muhittin Ataman \\ Mehmet Öztürk}

\section{Öz}

Uluslararası örgütlerin, dünyanın herhangi bir yerindeki devlet-içi çatışmaya çeşitli gerekçelerle ya müdahil olmayı seçtikleri ya da müdahil olmadıkları görülmektedir. Başta Birleşmiş Milletler olmak üzere uluslararası örgütlerin uluslararası barış ve güvenliği sağlama adına devlet-içi çatışmaları sonlandırması arzu edilen bir durumdur. Müdahale etmeleri durumunda nadir de olsa başarılı sonuçlar alınabilmektedir. Bununla birlikte, devlet-içi çatışmaları sonlandırmak için harekete geçen uluslararası örgütlerin başarısız olduğu durumlar olabilmektedir. Uluslararası örgütlerin devlet-içi çatışmalara müdahalesinin başarısız olmasının bazı önemli nedenleri bulunmaktadır. Hangi durumlarda başarısız olduğuna dair literatürde farklı bakış açıları mevcuttur. Bu makalenin amacı da uluslararası örgütlerin devlet-içi çatışmalara müdahalelerinde başarısız olma nedenlerini sınıflandırmak ve analiz etmektir.

Anahtar Kelimeler: Uluslararası Örgütler, Devlet-İçi Çatışma, Başarısızlık, Müdahale.

Bu makale, "Birleşmiş Milletlerin Afrika'daki Devlet-İçi Çatışmalara Müdahale Politikaları" isimli doktora tezinden üretilmiştir.

Prof. Dr. Ankara Sosyal Bilimler Üniversitesi, Uluslararası İlişkiler Bölümü, Ankara/ Türkiye, muhittin.ataman@asbu.edu.tr

Yrd. Doç. Dr. Aksaray Üniversitesi, Uluslararası İlişkiler Bölümü, Aksaray/Türkiye, mehmetozturk@aksaray.edu.tr

Bu makale iThenticate sistemi tarafından taranmıştır.

Makale gönderim tarihi: 5.10.2017

DOİ: 10.17550/akademikincelemeler.342455 


\begin{abstract}
It appears that international organizations prefer to intervene or not to intervene in intra-state or internal conflict anywhere in the world for different reasons. It is expected that international organizations, especially the United Nations, solve internal conflicts to provide international peace and security. In case of intervention of international organizations, successful results can be obtained in some cases. However, there are many cases in which international organizations fail to resolve internal conflicts. There are some important reasons for the failure of the interventions of international organizations. There are different perspectives in the literature explaining in which circumstances do interventions of international organizations fail. The purpose of this paper is to analyze and classify causes of the failure of interventions of international organizations to intra-state conflicts.
\end{abstract}

Keywords: International Organizations, Intra-state Conflict, Failure, Intervention. 


\section{Giriș}

İlk uluslararası örgüt olarak kabul edilen ve 1815'te Ren Nehri'nde seyrüsefer için kurulan "Merkezi Komisyon"dan günümüze çok sayıda uluslararası örgüt kurulmuştur. Çok değişik amaçlarla kurulmuş olan bu örgütlerden bazıları varlığını koruyamamışken, bazıları mevcudiyetini devam ettirebilmiştir. Varlığını sürdüren ve başta Birleşmiş Milletler (BM) olmak üzere uluslararası barış ve güvenliğin sağlanmasına hizmet etmeyi amaçlayan örgütlerin işlevlerini yerine getirip getiremedikleri öteden beri üzerinde tartışma yürütülen önemli bir konu olmuştur.

Uluslararası örgütlerin işlevlerini yerine getirip getiremedikleri ya da kısaca kuruluş amaçlarını gerçekleştirip gerçekleştiremedikleri birçok bilimsel faaliyetin temasını teşkil ettiği görülmektedir. Örneğin, "Uluslararası Kuruluşlar İşini Yapıyor Mu?” isimli yıllık toplantıya katılan Thomas M. Franck'e göre, ilgili toplantıda ele alınan konulara bakıldığında, üç konuda başarı göze çarpmaktadır. Her şeyden önce, küresel bir ekonomi ve genişleyen bir pazar yaratmada başarı vardır. GATT'ın DTÖ'ye dönüşümü; Avrupa Topluluğu'nun Avrupa Birliği'ne dönüşümü; ABD-Kanada Serbest Ticaret Bölgesi'nin NAFTA'ya dönüşmesi gibi. İkinci başarı, toplu güvenlik ve uyuşmazlık çözüm mekanizmalarının kurulması olmuştur. Örneğin, Birleşmiş Milletler Güvenlik Konseyi (BMGK) ve Genel Kurul'un Basra Körfezi, Namibya, Kamboçya, Mozambik ve Haiti'deki gibi faaliyetleri üstlenme ve yetkilendirme kapasitesinde son elli y1lda kayda değer bir gelişme gözlenmiştir. Son olarak, özellikle üçüncü dünya ülkelerinin davaya katılımında (Çad-Libya, Kamerun-Nijerya, El Salvador-Honduras vb.) Uluslararası Adalet Divanı'nın (ICJ) rolü artmıştır. Hepsi başarı gibi görünen bu gelişmelerin yanı sıra Franck, uluslararası örgütlerin neden zaman zaman başarısız olduğunu da analiz etmektedir. Aslında uluslararası örgütlerin başarısının başarısızlıkla sonuçlanan bir döngü şeklinde cereyan ettiğini öne süren Franck, bunun bu şekilde devam etmemesi için demokratik kurumların demokratik yetersizliğinin ele alınması gerektiğinden söz eder (1996: 596-598).

Mikiyasu Nakayama da uluslararası sular üzerinde uluslararası örgütlerin etkinliğini incelediği çalışmasında; uluslararası örgütlerin, 
kıyıdaş ülkeler arasında çatışmaları hafifletmek için bir mekanizma olarak hizmet etmelerinin beklendiğini ancak uluslararası örgütlerin şimdiye kadar böyle bir rol oynamak konusunda çok sınırlı bir başarı elde ettiğini dile getirmektedir. Uluslararası bir örgüt, sınır aşan bir su sisteminde ancak bazı kritik koşullar (kıyıdaş ülkelerin işbirliği yapmaya istekli olmaları, en üst düzeyde karar alıcıların dahil olması ve tarafsızlık) sağlandığında arabuluculuk yapmak için harekete geçebileceğini, bununla birlikte, uluslararası örgütlerin bugüne kadar böyle bir rol oynama konusunda çok sınırlı bir başarısı olduğundan söz eder (1997: 367)

İşlevsellikle bağlantılı bazı çalışmalarda ise uluslararası örgütlerin doğrudan başarısızlığına odaklanıldığı görülmektedir. Örneğin, Alastair Smith, IMF ve Dünya Bankası örnekleri üzerinden önümüzdeki on yıllar boyunca bu kuruluşların yoksulluğu hafifletme girişimlerinde başarısız olacağını öngörürken (2005: 565), Giulio M. Gallarotti ise bizzat uluslararası örgütlerin başarısızlığı üzerinden çalışmasını şekillendirmektedir. Uluslararası ilişkilerde uluslararası örgütlerin başarısızlı̆̆ının sistemik ve sistematik olmayan olmak üzere ikiye ayrılabileceğini belirten Gallarotti'ye göre; sistematik olmayan başarısızlıklar, uluslararası sorunların yönetimindeki hatalar veya arızalarla ilgiliyken, sistematik arızalar uluslararası örgütlerin doğasında veya bunlara özgü olarak kabul edilir. Yine ona göre, sistematik olmayan arızalar kaotik bir dağılıma sahipken, sistematik başarısızlıklar önyargıla yani başarısızlığı teşvik eden uluslararası örgütlerin rolleri, fonksiyonları ve hedefleri ile belirlenir (1991: 192).

$\mathrm{Bu}$ özellikleri itibariyle "sınırlı uluslararası örgüt" kavramını tercih eden Gallarotti’ye (1991: 211) referansla uluslararası örgütlerin bir takım sınırlılıkları barındırdıklarını dikkate alarak ve uluslararası örgütlerin özellikle devlet-içi çatışmalara müdahalelerine odaklanarak, söz konusu müdahalelerinde neden başarısızlık yaşadıklarını ele alacağız. Uluslararası literatürde doğrudan cevap getirilemeyen bir soruya da cevap niteliğindeki bu çalışmada, uluslararası örgütlerin devlet-içi çatışmalara müdahalelerinde neden başarısız oldukları üzerinde durulacaktır. Bu başarısızlığa etki eden faktörler, ilgili literatür ve teorik argümanlar dikkate alınarak şu şekilde tasnif ederek incelenebilir. 


\section{Dıș Müdahalenin Güvensizlik Yaratması}

Robert Cox ve Frankfurt Okulu'nun sosyal teorisyenleri başta olmak üzere eleştirel teorisyenler eleştirilerine teorinin hiçbir zaman siyasal olarak tarafsız olmadığı ve daima birileri için olduğu argümanıyla başlarlar. Bu teoriye göre, barış operasyonları neo-liberal ekonomik düzeni korumayı veya uluslararası toplumun kaotik yerlerine yönelik demokrasinin normalleşmesini zorlamayı amaç edinmiştir. Bu açıdan uluslararası barış ve güvenlik görünüşte periferi bölgeler oluşturan kapitalist ekonomiyle uyumludur (Bellamy ve Williams 2013: 27-28).

Bull gibi İngiliz Okulu temsilcileri ise Batılı liberallerin temel insan haklarıyla ilgili fikirlerinin, Batılı olmayan bölgelerdeki birçok toplum ve gruba çekici gelmediğini görmeleri gerektiğinden söz etmektedirler. Uluslararası toplumda düzen ve adalet arasındaki zıtlaşma aynı zamanda bir algılama farklılığını, bir başka deyişle Batı ve Batı-dışının farklı pencerelerden olaylara baktığını da göstermektedir. Örneğin, düzen ve istikrar nükleer yayılmayı önleyecek uğraşları öngörürken, adalet tüm devletlerin öz savunmaları için çok önemli gördükleri silahları elde etme hakkını beraberinde getirir. Yine NATO'nun 1999'da Sırbistan'a karşı gerçekleştirdiği askeri harekât, Blair gibi liderlerce dünyanın cani rejimlerden kurtarılması gerekliliğinin bir sonucu olarak okunurken, başkaları tarafından 'yeni sömürgecilik' olarak okunabilmektedir. Bu açıdan bakıldığında, Batı dünyası küresel adaletten ziyade düzenle ilgilenirken, Batılı olmayan dünya küresel adalet ihtiyacına vurgu yapmaktadır (Linklater 2012: 132).

Özellikle Afrika'nın yaşadığı uzun sömürgecilik mirası adı geçen sömürgecilik ve yeni sömürgecilik algılamasında pay sahibidir. Zaten pek çok Afrika ülkesinin siyasal sistemi sömürgecilikten kalma mirastır. Bu konuda ismi ön plana çıkmış Mahmood Mamdani'nin deyişiyle, sömürgelerin Afrika Kıtası'nda öngördükleri yönetim pratiği iki başlılık esasına dayalı, "merkezileştirilmiş despot" bir sistemdir. Bu iki başlılığın bir tarafını medeni hukukla yönetilen ve yönetenle yönetilen arasında vatandaşlık bağının bulunduğu merkezi devlet alanı teşkil etmekteydi. Diğer tarafı, geleneksel hukukla yönetilen ve yönetenle yönetilen arasında dini ya da etnik bağların olduğu yerel otorite alanından ibaretti. Bunu sömürge devleti sömürgeleştirilenlere bırakmakta 
ve yerel şeflerin iktidar ve hukukuna karışmamaktaydı. Ayrıca birinci taraf ırkçılı̆̆ 1 , ikinci taraf ise farklı etnik grupların varlığını mutlaklaştırmıştır. Milliyetçi hareketlerin 20. yüzyılın ikinci yarısında güçlenmesiyle devlete ve ırkçı hukukuna karşı sömürgecilik karşıtı mücadeleler gelişmiştir. Sömürgecilik karşıtı hareketler, hedeflerine merkezi devletin el değiştirmesini koyarlarken, yerel devleti ise otantik olarak görüp ezilme ve dışlanma alanı olarak görmüşlerdir. Sömürgecilik karşıtı hareketler başarılı oldukları yerlerde beyaz yöneticiler ve kolonyal işbirlikçi etnik gruplar görevlerinden alınıp yerlerine siyah yönetimler gelmiştir. Yerel devletin alanına dokunulmadığı bu süreçte ulus-devlet, geleneksel hukukun egemen olduğu yerel güç odaklarının üzerine kurgulanmıştır. Mamdani’nin (1996) vurguladığı gibi sömürgecilik karşıtı hareketler, "devleti ırksızlaştırırken etniksizleştirememiş ve çoğul hukuka ve toplumsal eşitsizliğe dayalı sömürgecilikten miras bir sistem kurumsallaşmıştır.” Burada devletin fonksiyonu ise dışlayıcı grup haklarının ve ayrıcalıklarının uygulayıcısı olmayı sürdürmekten ibaret kalmıştır (Aktaran Balta Paker 2012: 55-56).

Yine bu konuda ismi ön plana çıkan John Galtung'a göre, emperyalizmin ${ }^{1}$ yeni- sömürgecilik aşamas1; kontrolün geçmişe oranla daha az somut olduğu ve iki merkez arası bağlantının üye oldukları ve belli bir sürekliliğe sahip uluslararası kurumlarca sağlandığı bir süreçtir. Aralarındaki çıkar uyumu uluslararası kurumlar içinde tam bir eşitliğe dönüşebildiği gibi tam tersi durum da söz konusudur. Galtung, haklı olarak uluslararası kurumların illaki emperyalizme hizmet edecekleri anlamına gelmeyeceği ve kurum içi işbölümü ve kurumun feodal olarak organize edilme derecesi şeklinde değişiklik gösterebileceği hatırlatmasını da ekleyerek, yeni sömürgecilik aşamasında kurumların beş çeşit emperyalizm içinde görülebileceğini belirtmektedir. Bu anlamda siyasi emperyalizm için uluslararası kurumlar, askeri emperyalizm için çeşitli askeri ittifaklar, antlaşma ve kurum sistemleri (MIGO’lar),

1 Galtung, emperyalizmi merkez ve çevre metaforu üzerinden tanımlarken, şu varsayımlardan hareket etmektedir: Merkez ulustaki merkezle çevre ulusta iyi seçilmiş bir destekçisi yani çevre ulustaki merkezle bir çıkar uyumu vardır. Çevre ulustaki çevreyle merkez ulustaki çevre arasında çıkar uyuşmazlığı söz konusudur. Merkez ulustakine nazaran çevre ulusların içinde daha fazla çıkar uyuşmazlığı hakimdir (Galtung 2004a: 30). 
ekonomik emperyalizm için özel ya da kamu çok-uluslu şirketler (BINGO'lar), kültürel emperyalizm için uluslararası sivil kurumlar (INGO'lar) ve iletişim için gemicilik ve hava şirketleri (CONGO'lar) ve uluslararası basın ajansları iletim mekanizması işlevi görebilmektedirler. Galtung'a göre, üçüncü aşamada ise bu söz konusu kurumlara tele uydular vb. geçici iletişim ağları gibi alternatiflerin ortaya çıktığı ve kurumların eleştirilerek etkilerinin azalacağı öngörülmektedir. Dolayısıyla, Galtung'un kavramsallaştırmalarında uluslararası kurumlar beş aşamalı gelişim gösteren emperyalist hakimiyet aracı olarak görülmektedir (2004b: 39-42).

Bilhassa gelişmekte olan ülkeler insan hakları hususunda metropoliten merkezlerden yükselen seslerin kendi iç işlerine karışmak için bir bahane olduğu fikrini taşırken, diğer yandan toprak merkezli egemenliğin, meşru uluslararası gözetimden kaçma yönünde kullanılmayacağına ilişkin artan bir kabul vardır. Bununla birlikte, çok sayıda devlet, etik performanslarını geliştirme konusunda başkalarına kendileri üzerinde baskı kurma hakkı vermeye pek yanaşmamaktadırlar. Tabii bunda artan insani müdahalelerin vuku bulduğu endişeyi de göz ardı etmemek gerekir (Burchill 2012: 98). Bu anlamda örneğin, Gana'nın ilk devlet başkanı olan, pan-Afrikanizmin öncüsü ve Afrika Birliği fikrinin ilham kaynağı olarak görülen Kwahe Nkrumah'ın; Afrika'nın neo-kolonyalizme ve Balkanlaşmaya zemin hazırlamaması için birleşmek zorunda (Soutball 2006: 220) olduğuna işaret etmesi bu endişenin ürünü olarak görülebilir. Kaldı ki, her uluslararası müdahalenin oluşturduğu güvensizlik nedeniyle etkili olamayabileceği, hatta çatışmayı hafifletme çabalarını daha da karmaşıklaştırabileceği göz önünde bulundurulmalıdır. Somali' de 1993'teki BM barışı koruma birliği ve Afrika Birliği'nin Sudan'da 2007'deki barış koruyucuları örneklerinde görüldüğü üzere savaşan taraflar dış müdahaleyi pusu olarak görüp güvensizlik duymuşlardır (Jeong 2008: 194-196).

\section{Müdahale Eden Aktörün Yaşadığı Sorunlar}

Müdahaleleri etkisiz kılan bir başka faktör, müdahale eden aktörün yaşadığı sorunlardır. Örneğin BM'nin 5 daimi üyesinin veto gücü üzerine inşa edilmiş olması nedeniyle müdahalelerinde belirgin bir başarı elde edemeyeceği görüşü hakimdir (Newman 2011: 339). Soğuk Savaş son- 
rası dönemde BM Soğuk Savaş dönemine göre daha iyi işlemekle beraber halen problemleri olduğu genel kabul görmektedir. BMGK'nin üyelerinin veto güçlerinin yanı sıra BM'nin Ortadoğu ve Balkanlarda küçük ülkelerden oluşturduğu zayıf ve yetersiz barış güçlerinin başarılı olamadığı hatta Kamboçya'da Kızıl Kmerler'in BM barış gücü askerlerini kaçırabildiği örneğinden de BM'nin uygulama gücündeki problem gözler önüne serilmekte, bu yapısı da onun "dedikodu ortamı olarak kaldığı" yakıştırmasına neden olmuştur (Roskin vd. 2013: 385386).

1945 sonrası güç dengesinin ürünü olan BM'ye ilişkin son dönemlerde eleştirilerin dozu artmıştır. BMGK'ndeki daimi üyelik ve veto sistemi BM'ye karşı eleştirilerin odağı haline gelmiştir. Nüfus büyüklüğü ve yoğunluğu itibariyle meşru durumu ve ekonomik gelişme düzeyleri farklı üye devletleri birleştiren BM Genel Kurul'unda her üye devletin kendi sesi varken, BMGK'nin oluşumu ve üyelerinin oy verme hakları gerçek güç ilişkilerini yansıtmaktadır. BM kararları, ulusal hükümetlerin birbirinin egemenliğine saygı göstermeyi, insan haklarını gözetmelerini ve askeri güç kullanımından kaçınmalarını gerektirmektedir (Habermas 2008: 644).

When Knowledge is Power isimli eserinde çok sayıda uluslararası örgütün göreceli etkisizliğinden hareketle onların sürekli bir öğrenim faaliyeti içinde olmalarını sağlayacak bir yeniden yapılandırılmaya gereksinimleri olduğu tespitinde bulunan Ernst Haas, BM gibi uluslararası örgütlerin, daima öncelik verilen spesifik bir amacın aracı olmaktan ziyade doğrudan amaç olarak düşünülmesi gerektiğini öne sürmektedir. Bu yapıldığı takdirde uluslararası örgütler yeni sorunlara adapte olabilirler ve tek başına başlamak için fazlaca iddialı olunan bazı amaçların yerine getirilmesindeki başarısızlıkları ön plana çıkmaz. Tangle of Hopes isimli kitabında ise sistem dönüşümünü iki model ile açıklayan Haas, bunlardan birincisini otonom içsel değişime ikincisinin ise geribildirime bağl1 olduğunu; bunlardan birincisini devletlerin içindeki değişimlerin yeni talep ve politikalara sebep olmasıyla, ikincisini ise uluslararası örgütlerin performanslarıyla ilgili tecrübelerin karar vericileri neyi etkin yapabileceği ve izlenecek yeni amaçlar formüle etmeleriyle ilişkilendirmektedir. Söz konusu geri bildirimlerin elitler arasında uyarlanıp öğrenmeye sebep olduğu takdirde 
daha güçlü bir sistem olacağını ve $A B D$ ve $B M$ arasında gözlemlendiği gibi artan karşılıklı bağımlılığa gidebileceğini belirten Haas, otonom içsel değişimde ise örgütün değişen taleplerini takip etmede zorlanması sonucu durağan kalacağını öngörmektedir (Aktaran Griffiths, Roach ve Solomon 2011: 95-96).

Robert A. Dahl da demokratik olmayan ülkelerde, demokrasi dış1lıktan daha demokratik bir yönetime geçişe yardımcı olma ve insan hakları ve hukukun üstünlügü ilkesinin genişletilmesine katkı noktasında hemfikir olmakla beraber, uluslararası örgütlerin demokratik olmadığını ve güçlü bir ortak kimliğin yokluğunda kolayca içsel bir gerilimi tetikleyeceğini düşünür (2008: 637-638).

$\mathrm{Bu}$ arada, BM örneğinde görüldüğ̈̈ üzere uluslararası örgütlerin karşılaştığı kısıtlamalar ve sorunlardan bir kaçı; maliyet, karmaşık operasyon oluştururken uygunsuz bürokratik yapılar ve külfetli karar verme süreçleridir. Uluslararası örgüt himayesi altında barışı korumanın da bir operasyonun meşruiyetini yeterince sağlamayacağı öngörülmektedir. Ayrıca uluslararası meşruiyet örgüte, tarihsel bağlama ve müdahalenin kendi doğasına bağlıdır. Örgütlerin sadece üyelik, amaç, bürokratik yapı ve meşruluk işlevi değil aynı zamanda onların yetenekleri, rolü ve ahlaki duruşu da önemlidir (Bellamy ve Williams 2013: 46-47).

Uluslararası örgütlerin yürüttükleri operasyonlara ilişkin sorunlar ise şöyle sıralanmaktadır. Birincisi, genellikle katılan ülkelerden seçilmekle beraber komuta gücünün kimde olacağına ilişkindir. İkincisi, misyon personeline ortak eğitim verilmemesidir. Üçüncüsü, sembolik olarak özellikle bir ülkenin operasyona liderlik etmede görevli olmadığı durumlarda, uygulamada her askeri birlik kendi en yüksek rütbeli ulusal yetkilinin kendi özgür kararı ile hareket etme ve kendi hükümetinin etkisi altında kalabilme esnekliğine haiz olabilmektedir. Ayrıca her bir güç öğesi barışı koruma tecrübesi bakımından farklılık arz edebilir, onların temel askeri yeterliliklerinin yanı sıra konuşulan dil de önem arz eder (Bellamy ve Williams 2013: 57-58). Eğitim ve dil sorunu küçük ama önemli bir ayrıntıdır. Belli standartlara kavuşmamış barış güçlerin bu sorununa ilave olarak görevli birliklerin kendi aralarında ve görev aldıkları bölgenin yerel halkıyla iletişim güçlükleri 
önemli bir problemdir (Yılmaz 2007: 56-57). Ayrıca, insani müdahale açısından uygun ve zamanında cevap için hazırlık eksikliği temel sınırlama olarak görülmektedir (Deng 2013: 339).

Kurumsal komuta ve kontrol kapasitelerindeki eksikliklerin BM koruma gücünü tersi yönde etki edebilmesine Angola, Bosna, Kamboçya, Kongo, Ruanda, Sierra Leone gibi yerlerin yanı sıra Somali'de bireysel birliklerin tek taraflı eylemlerinin operasyonları zora sokması örnek olarak öne çıkartılabilir. Bununla birlikte barışı korumaya katılımın gönüllü olması nedeniyle personelin profesyonellik niteliği ve öncelik motivasyonları değişebilmektedir (Bellamy ve Williams 2013: 58). Eğer müdahale yetkisi genişletildiğinde müdahale gücüne ek kaynaklar verilemezse veya yeni yükümlülük kuralları verilmezse başarı şansı düşer. Siyasi liderler de maalesef ek açık maliyetlere ${ }^{2}$ girmeden daha çoğunu başarmaya çalışmaktadırlar (Seybolt 2008: 45).

Örneğin, Ruanda'daki soykırımı önleme ve durdurmada BM'nin temel başarısızlığı siyasi uzlaşı ve kaynak eksikliğiydi. BMGK tarafından siyasi irade eksikliğine rağmen oluşturulan United Nations Asistance Mission for Rwanda (UNAMIR) benzer sorunlardan mustarip olmuştu. Ayrıca başlıca şu yönlerden başarısız olmuştur: Korumada başarısızlık, örgütsel yetersizlik, bilgi akışı, analitik yetenek eksikli$\breve{g i}$, ateşkese uygunsuzluk, odaklanma, lojistik ve kaynakların eksikliği, yükümlülük kurallarına ilişkin karışıklık, yetkinin uygulanmasında ve bizzat yetkide yetersizlik ve bunlarla ilintili olarak soykırıma cevap vermede başarısızlık (Bellamy ve Williams 2013: 115-116).

Müdahalenin genellikle başarısız olmasında diğer neden pratikte müdahale tipleri arasındaki ayrımın çok belirgin olmamasıdır. Bir müdahale tipi seçildiğinde genellikle diğeriyle sonuçlanmaktadır. Örneğin, yardım örgütlerini korumak için gönderilen bir askeri güç yoğun baskıya uğradığında yetki genişlemesine sebep olabilmekte ve hatta bu misyonda deformasyona yol açabilmektedir. Bu arada yabancı yardım

2 Carter'ın, BM'nin stratejik olarak başarı olasılığı yüksek olan yerlerde barışı korumayı seçtiği şeklindeki iddiasına Gilligan ve Stedman'ın askeri olarak güçlü ülkelere müdahalede risk ve maliyet faktörünü düşünerek BM'nin müdahaleden kaçındığı şeklindeki iddiasını ekleyen Fortna, özellikle rızaya dayalı misyonların kolaydan ziyade zor durumlarda seçildiğini öne sürmektedir (2007: 19-20). 
çalışanlarını korumanın yerel nüfusu korumaktan daha kolay olduğu dikkat çekicidir. Çünkü yardım çalışanları sayı olarak daha azdırlar, çok dağınık değillerdir, kolayca güvenli bölgelere çekilebilirler ve gerektiğinde ülkeden ayrılabilirler. Bir başka başarısızlık nedeni de bir müdahalenin stratejik gereksinimleri küçümsemesidir. Karar vericiler insanların acısının nedenlerini doğru teşhis etmelerine ve uygun aktörlere odaklanmayı kararlaştırmış olsalar da onlar genellikle ilgili stratejik gereksinimleri gerçekleştirmede başarısızlığa düşmektedirler. Bu, karar vericilerin nüfusu korumada görece daha kolay olan caydırıcılığı zorlamaya tercih etmeleriyle (BM birliklerinin Saraybosna'daki Sirp birliklerini caydırmayı başaramaması gibi) ya da karar vericiler doğru strateji seçseler bile başarı şansını artıracak en iyi strateji gereksinimlerini anlayamamalarından (yeterince güçlü askeri birliğe sahip olmayan BM Sırpların Srebrenika'yı istila etmesini önleyememesinden) ileri gelmektedir (Seybolt 2008: 44-45).

BM'nin yayınlamış olduğu Srebrenika katliamına ilişkin raporda, güvenli bölge belirlenmiş olmakla birlikte üç önemli noktada hata yapıldığının altı çizilmekteydi: BMGK'nde genel konsensüs olmadan barış koruyucuların konuşlandırılması; böylece yeterli kaynaklarca desteklenmemesi; ve uluslararası hukukta ifadesini bulan "korunak11 bölgeler" ile "güvenli bölgeler/barınaklar" arasındaki ayrımın kafa karıştırmasıdır. Bunlardan birincisi askerden arındırılmış, çatışanların rızasını arayan ve uluslararası insancıl hukukun yetkisi altında oluşturulan yerleri tanımlarken, ikincisi, askerden temizlenmemiş, güvenilir bir askeri caydırıcının yokluğunun hissedildiği ve çatışanların rızasının aranmadığı yerlere işaret eder. Bosna' da BMGK'nce güvenli bölgeler oluşturulurken tarafların rızasının alınmadığı görülürken ve herhangi bir güvenilir askeri caydırıcılık şartının yokluğu da hissedilmiştir. Temel bir ders olarak soykırım ve etnik temizlik stratejisi kesin olarak bütün gerekli araçları ve siyasi iradeyi meydana getirebilirdi. Ancak sadece uygun tehdit ve güç kullanımının sivilleri koruma ve saldırıları caydırması olası olmakla birlikte UNPROFOR ve UNAMIR bu rolü yerine getirebilecek yeterli donanıma sahip olmamışlardır (Bellamy ve Williams 2013: 117-119).

BM'nin başarısızlık örneklerinin yanı sıra bölgesel örgütlerde de etkinlik sorunları görülebilmektedir. Soğuk Savaş döneminde Af- 
rika Birliği’nin bölge içi çatışma yönetiminde başarılı olamadığı, her ne kadar BM'nin yükünü hafifletse de siyasi kararlarının süper güçlere bağımlı olduğu bir gerçekti (Meyers 1974: 345). 1963'te kurulan Afrika Birliği'nin ilk planladığı strateji Afrika'nın çatışmalarıyla meşgul olmaktı. 1993 y1lında çatışma önleme, yönetme ve çözme mekanizmas1 kuran Afrika Birliği, Soğuk Savaş sonrası düzende kapasite, kaynak ve tecrübe eksikliğini çok hissetmiştir (Olonisakin 2006: 277-278). Çatışmaların önlenmesi ve çözülmesinde Afrika Birliği gibi kısmen etkili olabilen bölgesel örgütler aynı oranda operasyonların kapsam darlığı ve çıkar merkezli davranışları nedeniyle etkisiz kalabilmektedirler. ASEAN ve OAS gibi bölgesel örgütler ise meşruiyet eksikliği ve yetersiz maddi kaynaklar nedeniyle etkisiz kalmaktadır (Özerdem 2013: 108-109).

Sohail H. Hashmi de günümüz İslam dünyasında insani müdahale pratiğinin ümit kırıcı bir durumda olduğunu düşünmektedir. Öncelikle gerekli acil kolektif müdahale gerektiren insani krizlerde müşterek destekli acil kolektif müdahale yapısının yokluğu ve kolektif müdahaleye yönelik uluslararası kararları uygulayacak dayanıklı kurumsal mekanizmanın eksikliği bu uğurda karşılaşılan başlıca problemlerdir. 1969'dan beri varlığını sürdüren İslam İşbirliği Teşkilatı'nın 'evrensel İslam etiği' söyleminin kendi aralarındaki düşmanlık ve farkl1lıklar nedeniyle istenilen çizgiye oturmadığı ortadadır (2003: 78).

\section{Müdahalenin Sorunu Derinleştirme İhtimali}

Hızla artan sayıda uluslararası ilişkiler akademisyenleri, hükümetler arası örgütlerin (IGO), barışı teşvik ettiklerini iddia ederler. Var olan yaklaşımlar, IGO üyeliğini, ekonomik kalkınma ve rejim tipi gibi bireysel devletlerin önemli nedensel özelliği olarak vurgularlar. Buna karşın, hiç de azımsanmayacak sayıda akademisyen bu görüşün tersini savunmaktadırlar. Bunlardan örneğin Emilie M. Hafner-Burton ve Alexander H. Montgomery, çalışmalarında IGO üyeliğinin sosyal gücün bambaşka dağılımına yol açtığını göstermek için sosyal ağ analizini kullanmışlardır. Çalışmalarında liberal argümanlardan farklı yapısal realizme yakın çok sayıda argüman sunmaktadırlar. Mesela, uluslararası güç politikası ortamında devletler arasında gerçekleşen ilişkilerde çatışmaların kaynaklarının seyrini saptamaya çalışmaktadırlar. 
IGO'ları; barış yapmayı teşvik etmekten ziyade, çatışma üreten güç politikasının araçları olarak tanımlamaktadırlar (2005: 1-2).

IGO'ların çatışmayı mı yoksa barışı mı teşvik ettiğinin en önemli göstergelerinden birisi müdahale konusu olmuştur. Bu konuda örneğin Robert O. Keohane, egemenlik kurumunun müdahaleyi sinırlama yoluyla yönetenlerin çıkarlarına hizmet ettiği görüşünden hareketle, müdahalenin bölünmeyi ve devlet-içi çatışmayı körükleyerek sivil toplum karşısında yöneticilerin iktidarını zayıflattığını düşünmektedir (2008: 184). Downs, Rocke, Siverson, Van Evera ve Jervis'e atıfla idrak ve inançları da içinde barındıran algının önemine vurgu yapan Axelrod ve Keohane ise, özellikle bir devlet-içi çatışmaya yönelik müdahalecilerin kararında algılamanın önemli olduğunu hatırlatırlar (2013: 362-363). Müdahalecilerin kararında bilhassa düşmanın yeteneklerini yanlış alg1lama oldukça önemli olabilmektedir. Düşmanın yeteneklerinin düşük tahmin edildiğinde askeri aşırı güven ve maliyet oranı düşük bir şekilde hızlı bir galibiyet beklentisi ortaya çıkarırken, düşman yeteneklerinin gereğinden fazla tahmin edilmesi ise aşırı reaksiyon ya da silah yarışına sebep olabilmektedir. Aynı yanlış algılamalar üçüncü tarafların yetenekleri ve niyetleri için de söz konusudur (Levy 2001: 18).

Evren Balta Paker de Afrika'nın pek çok ülkesinde cereyan eden insani müdahalelerin hükümetlerin insansızlaştırma gibi muhalefet karşıtı taktiklerine hizmet ettiğini ve uluslararası örgütlerin yiyecek ve barınma yardımlarının kısa dönemli gereksinimler için gerekli olsa da uzun dönemli kapalı kamplarda tutulan yerinden sürülmüş grupların bu konumunu meşrulaştırdığını iddia eder (2012: 68-69). $\mathrm{Bu}$, girişilen insani müdahalenin iki önemli etkisiyle bağlantılıdır. Birincisi, yardım ajansları ve askeri güçlerin kendi siyasal rollerini farkına varmaksızın istemeden çatışmayı kötüleştirmeleri olasıdır. Örneğin, ABD güçleri Somali' de sadece insanların beslenmesine yardım etmede ısrarcı olmuşlardır. İkinci olarak, bundan dolayı hükümetler sivillere yardım etmek için birliklerini bir araya getirirken siyasi çıkarların insani olanları etkisi altına almadığı sürece birliklerini risk altındaki siyasi ve insani çıkarlara sahip oldukları için teslim ederler. Yerel savaşanlar da siyasal çıkarlarını korumak için savaşırlar. İnsani çıkarlarla hareket eden müdahilin sadece şiddet düzeyi arttığında ve askerleri öldürüldüğünde geri çekilmesi olasıdır. Ancak hem siyasi 
hem de insani çıkarlara sahip müdahilin belli kayıpları göze alması ve insanları koruması ve beslenmelerine yardımc1 olmayı sürdürmesi daha olasidir (Seybolt 2008: 27).

Bu gibi durumlara sebebiyet vermemek için üçüncü taraflar; uzlaş1 ve uygulamalarla yakından ilgilenmelidir. Müdahaleler dayanma gücü eksikliği ya da toplum içi uzlaşı sağlayacak kaynakların toplanmasındaki yeteneksizlik halinde de başarısız olabilecektir. Dayanma gücü başarıya ulaşmada makul beklentilerle birleşmek zorundadır ki bu müdahale hedefleri hayal kırıklı̆̆ına yol açacak kadar yüksek, sinikliğe davet edecek kadar da düşük olmamalıdır. Başarı ayrıca barış yapımı ve barış inşası girişimi ile de ilintilidir. Barış inşası $1^{3}$ sürecinde taraflar dış güçlerle beraber değil, kendileri geçiş süreci sorumluluğunu almalıdırlar. Aksi halde realistlerin de hatırlattığı üzere müdahaleler bazen durumu daha da kötüye götürebilir hatta çatışmayı tetikleyebilir (Hampson 2001: 401-402).

Devlet-içi çatışmaların güç zemininde çözümlenebileceğine ilişkin BM güçlerinin artan militarizmi başka bir sorun alanını teşkil eder. Soğuk Savaş döneminde BM Şartı'nın 6. Bölümünde öngörülen pasifist tedbirlerin zayıflı̆̆ını gidermek için Soğuk Savaş sonrasında zorlayıcı tedbirlerin ön plana çıkarılması söz konusu olsa da bu güce dayalı bir anlayışın yaygınlaşmasını da beraberinde getirmiştir. Bunun da tarafların rızası olmadan güç kullanma bir tarafa ölü ve yaralı sayısını artırarak barış tesis etmekten çok savaş görünümüne bürünme tehlikesi vardır. Ayrıca, BM’nin büyük güçlerin çıkarına hizmet eden örgüt ya da sömürgeci bir örgüt olarak görülmesine, güven duygusunu sarsmasına, barış güçlerinden yerel işbirliğinin çekilmesine, barış güçlerinin tarafsız olarak algılanmamaya başlanmasına bağlı olarak düşman ya da düşman işbirlikçisi olarak adlandırılmaya başlanmasına, sorunların asıl nedenlerine inilememesine sebebiyet vererek uyuşmazlığın sadece baskılanmasından öteye geçemediğine vurgu yapılmaktadir (Yılmaz 2007: 58-60).

3 Barış inşası operasyonları; genellikle Batı dünyasındaki barış ve kalkınma fikirlerini yansıttı̆̆ , askeri çatışmaların asıl nedenlerini göz ardı ettiği ve bazen silahlı çatışmaya kaynak sağlayan mevcut sosyal yapıyı devam ettirerek örneğin geri plandaki sosyal aktörleri görmezden geldiği gerekçesiyle eleştirilmektedir (Özerdem 2013: 83-84). 
Devlet-içi çatışmalarda güçlü tarafın güçsüz tarafı baskılaması çözümle aynı anlama gelmediği, söz konusu bastırmayı toplumsal bir travmaya dönüştüren gruplar önce genellikle küçük terör grupları halinde daha sonra ise merkezi otoriteye karşı çatışmaya girmektedirler. Ayrıca çatışmanın acısına doğrudan maruz kalmış kimseler, çatışmadan beslenen birey ve gruplar, barış koşullarını beğenmeyenler, toplumlararası uzlaşı için gerekli olan karşılıklı ödünde bulunmama, uzun süren çatışmalarda belli süre sonra karşı tarafın kaybediyor gibi algılamaya başlaması ve ulusal güç kullanımın makul olmaması halinde çatışmanın sürdürülmesi daha muhtemeldir (Yılmaz 2007: 63-65).

Önemli eleştirilerden birisi olan makul başarı şansı, yeterli şansa sahip olacak yeterli çabayı başlatma ve kesin maliyetlere katlanma istekliliğini gerektirir. İç savaşlarda başarı tanımı bir tarafın yenilmesi ve kazananın kaybedenler üzerinde şartlarını kabul ettirmesi olarak görülmektedir. Oysaki insan haklarını ihlal edenlerin yenilgisi sadece uzun bir düzenin başlangıcı ve uluslararası toplumca daha fazlasını gerektiren bir süreçtir. Askeri zafer sonrası dışarıdan ya da dış güçlerce bir devletin inşası/yeniden inşasının risk altında olduğu aşikârdır. Kamboçya, Angola, Somali örnekleri bunu doğrulamaktadır (Hoffmann 2001: 280).

Nitekim, kaderleri ve kaynakları kayıt dışı ekonomi ve uluslararası yardım ağlarına bırakılan gölge devletlerin devlet olma özelliğini yitirerek eşitler arasında birinci bile olmaktan aciz ve çatışan taraflardan biri haline geldiği böyle bir ortamda, BM'nin 1990'l1 yıllarda müdahale ettiği vakalar önemli ipuçları taşır (Balta Paker 2012: 71). Somali gibi yerlerde durumu daha da vahim hale getiren barış koruyucular, Demokratik Kongo Cumhuriyeti, Somali ve Batı Afrika'da savaş lordlarıyla ticari münasebetler kurmaktan ve kadınlara cinsel şiddet uygulamaktan da geri durmadıkları gibi etkisiz barış koruyucular ve barış yapıcılar Darfur, Bosna ve Haiti gibi yerlerde anlaşmalar yapma yoluyla uzun süren anlaşmazlıkları çözmeye muvaffak olamamışlardır (Bellamy ve Williams 2013: 3).

Müdahaleler için en temel sorunu teşkil eden etkisiz bir müdahalenin sorunu derinleştirme ve çekilen acıları arttırma ihtimali ise uluslararası örgütlerin müdahalesini başarısız kılmaktadır (Newman 
2011: 339). Dolayısıyla, müdahale çoğu zaman “değecek amaçlar” uğruna olsa da faydadan ziyade zararla sonuçlanması muhtemeldir (Waltz 2013: 741). Bu bağlamda eski diktatörlerin yerini yabancı işgal güçlerinin almasının çatışmaları daha da alevlendireceği öne sürülmektedir. Bunun için insani müdahale uzun soluklu ve sadece acil durumlarda başvurulacak bir yöntem olmalıdır (Heywood 2013: 390-391).

Karar vericilerin bilgili ya da bilgisiz kararları ve yanlış neden üzerinde düşünceleri halinde de insani müdahale kötüye gidebilir. Bosna Hersek'te olduğu gibi yerlerinden sürülmüş halkın sürdürülemez yerleşim bölgelerine zorlanmaları, gıda ve sağlık yardımlarını koruma olmadan sağlamaya çalışmaları acil ihtiyacı beraberinde getirdiği gibi yer değiştiren insanların saldırılara maruz kalabildiği görülmektedir (Seybolt 2008: 43). Ayrica, NATO'nun Kosova'da sıfır kayıp stratejisinde olduğu gibi, sivillerin ölümünün orant1lık ve gereklilik üzerinden meşrulaştırılmaya çalışıldığı da olmuştur (Balta Paker 2012: 88).

Bir diğer başarısızlık nedeni de ana problemin üstesinden gelemeyeceğini bilmelerine karşın karar vericilerin daha kolay müdahale tipini kasten tercih etmeleridir. Örneğin Ruanda soykırımından sonra bir milyondan fazla Ruandalının sınırı geçerek Zaire'ye geçmelerinden sonra ideolojik olarak kendini adamış katillerin mülteci kamplarını kontrol etmeye başlamaları ve UNHCR'nin aşırılıkçılara karşı acil askeri yardım isteğinde hiçbir devletin öne çıkmaması, müdahaleye ilişkin risklere ve maliyetlere girmek istememeleri Zaire'de iki iç savaşa yol açarak 3 milyondan fazla insanın ölümüne yol açmıştır (Seybolt 2008: 44). Bu olayın arka planında ise BM'nin çatışma çözümü için önerdiği demokratikleşme ve seçim önerisi, seçimleri kaybedeceğini düşünen Hutuları daha da saldırganlaştırması vardır. Bu da müdahalenin, uluslararası dengeleri değiştirdiği gibi, iç dengelere yönelik de kalıcı hasarlar bırakabildiğini göstermektedir. Yine, BM'nin seçim çağrısı yaptığı Angola'da UNITA, 1992'deki kaybını telafi anlamında katliamlar gerçekleştirmiştir. Ayrıca, BM barış güçleri bizzat yerel şiddetin uygulayıcısı da olabilmektedir. Örneğin; BM güçlerinin soykırım esnasında Ruanda'dan çekilmesi, BM barış gücünün Kongo'da etnik katliamlara sessiz kalması ve BM barış gücü askerlerinin çok sayıda kadına tecavüz etmesi gibi. Bu türden olaylarda $\mathrm{BM}$ güçlerinin git- 
tikleri ülkelerde yargı dokunulmazlıkları bulunurken, o ülkedeki BM misyonunun iç soruşturma talep hakkı bulunmakta ve suçu sabit görülene verilen ceza ülkesine gönderilmesi ve orada yargılanması şeklinde cereyan etmektedir. Ancak deliller başka ülkede kaldığ 1 için bu yarg1lama da problemli olmaktadır (Balta Paker 2012: 94-95).

Öte yandan, Soğuk Savaş döneminden farklı olarak zengin devletlerin NATO'nun Yugoslavya'yı bombalaması gibi inisiyatiflerini hakl1 göstermek için ahlaki değerlere başvurduğunu öne süren Thomas W. Pogge; bir milyon kişiyi Sırp zulmünden korumak adına binlerce hayatı tehlikeye atmak ve milyonlar harcamak yerine, hiç kimsenin hayatını tehlikeye sokmadan milyonlarca kişiyi yoksulluktan kurtarmak için sözü edilen miktarları harcamanın daha mantıklı olacağını düşünmektedir (2008: 650). Fred Halliday ise; BM'nin 50. kuruluş yıldönümüne denk düşen Yugoslavya örneği temel alındığında eleştirilebileceğini ancak yine de BM'nin burada insani, diplomatik, barışı koruma alanlarında etkili olduğunu vurgular. Bunun yanı sıra Güvenlik Konseyi'nin çoğu çözümlerden geçerek aktif müdahaleyi sürdürdüğü ve hiç değilse yanlış yönetim ve yozlaş(tır)manın da içinde bulunduğu BM operasyonlarının başarısızlıklarını inkâr etmeden, burada olmuş olanların tüm sorumluluğunu BM'ye yükletilemeyeceği görüşünü savunmaktadır (2008: 581-582).

Müdahaleye ilişkin fayda-maliyet hesabı tartışmasında Andrew Heywood, bunun "asıl sonuçlarının varsayımsal" durumlardaki sonuçlarıyla değerlendirilmesi gereğinden yola çıarak bunun kolay çözümlenebilecek bir tartışma olmadığını savunur. Örneğin, Ruanda'da daha erken ve daha uyumlu bir müdahale olsaydı, soykırımın önlenebileceğine ilişkin yaygın düşüncenin hiçbir zaman kanıtlanamayacağını söyleyen Heywood, 1991'de Kuzey Irak, 1999'da Kosova ve Sierra Leone'e ilişkin müdahalelerin faydalı sonuçlar ortaya koyduğunu söylemektedir. Lakin BM'nin barışı koruma güçlerinin Kongo müdahalesinde olduğu gibi insani felaket gerçekleşirken devre dışı kaldığını, Somali'de olduğu gibi başarısız olduğu için kısa sürede sonlandırıldığını belirten Heywood, insani müdahale sayılmamakla birlikte Irak ve Afganistan müdahalelerinin isyanları "uzun süreli mücadele savaşlarını” meydana getirdiğini belirtmektedir (2013: 390). 
Bütün bu bilgiler 1şığında, tehlikeli ve pahalı bir girişim olan müdahalede siyasi ve insani kaygılar arasındaki dengenin hassas ve yine bunlar arasındaki ilişkilerin kırılgan ve son derece önemli olduğu söylenebilir. Eğer iyi bir şekilde gerçekleştirilmezse müdahalenin hayatları ve kaynakları israf etmesi ve sorunu içinden çıkılmaz hale getirebilmesi hatta savaşları beslemesi söz konusu olabilmektedir (Seybolt 2008: 5).

\section{Çatışan Tarafların Rızasının Alınmaması}

Çatışan tarafların aktif olarak rızasının alınmadığı 1990'lı yıllarda BMGK onayıyla müdahale gerçekleştirilirken, 2000'li yılarda BMGK'nin, onayı bile olmadan müdahale yapılabilmesi, büyük devletlerin çıkarlarının öncelendiği ve güçsüzün güçlüye tahakküm edildiği ikili bir hukuk sistemi oluşmuş ve buna göre yapılan uluslararası müdahale "egemenlik ilkesini aşan bir zorunluluğa" dayandırılmaya başlanmıştır. Benzer ayrım birinci ve yeni kuşak operasyonlarda ${ }^{4} \mathrm{da}$ görülmektedir. Birinci kuşak barış operasyonlarından farklı olarak yeni kuşak operasyonlar; soykırım vb. insani felaketleri önlemek için çatışmanın taraflarının rızasını alma ilkesini ilga etmektedir. Egemenlik ve otorite arasındaki ilişkiye dayanan bu durum 2000 yılında BM Genel Sekreter Yardımcısı Lakhdar Brahimi'nin ismiyle anılan raporda teyit edilmektedir. Brahimi Raporu'na göre; iç çatışmalara rıza gösteren grupların, bundan vazgeçme ya da söz konusu grupların bölünmesi sonucu ilk barış antlaşmasını inkâr eden yeni çatışmac1 grupların belirmesini dikkate alarak rıza ilkesinin mutlak ölçüde uygulanmasını sakıncalı ve imkânsız görmekteydi. Uluslararası aktörler, küresel bir anayasacılık fikri çerçevesinde bireysel egemenlik ve insan haklarına vurgu yaparak bunları başaramayan devletlere yönelik uluslararası adaletin müdahalesini öngörmektedir. Devletler müdahale etmedikleri zaman egemenlik ilkesine, müdahale ettikleri

\footnotetext{
4 Barış destek operasyonlarının başarısı, çatışan tarafların istekliliğine bağlıdır. Barış destek operasyonları ve barış inşası BM tarafından çok boyutlu operasyonlar olarak değerlendirilmektedir. Askeri aktiviteleri insani destek, kurumların inşası görevinde taraflar arasında uzlaşının sağlanmasına kadar her şeyi kapsayan barışı destek operasyonları, günümüzde daha çok barış inşası olarak adlandırılmaktadır (Olonisakin 2006:276).
} 
zaman da uluslararası sorumluluğa atıf yapmaya başlamışlardır (Balta Paker 2012: 81, 95).

11 Eylül sonrası süreç asimetrik stratejiler kullanan terörizme karşı devletlerin güvenlik örgütlenmelerinde caydırıcılıktan önleyici savaşa doğru bir dönüşüm geçirmesi, uluslararası hukukun meşru müdafaa gerektiren durumlar haricinde müdahale etmeme ilkesi ile çelişen bir durumu beraberinde getirmiştir (Balta Paker 2012: 43). Çünkü 11 Eylül saldırıları sonrasında sanayileşmiş dünyada sivil özgürlükler üzerinde yeni kısıtlamalar, artan gözaltına almalar, askeri harcamalarda artış, istihbaratın genişlemesi şeklinde vuku bulan devlet iktidarının yeniden güçlenmesi ve terör ve kitle imha silahları tehditleri $\mathrm{ABD}$ liderliğinde Afganistan ve Irak'ta devlet müdahalelerini beraberinde getirmiştir. Terör saldırıları tehdidi altında kalan devletler birbirinin iç işlerine karışma hatta önleyici müdahale etme yolunu seçmeye başlamışlardır. Önleyici müdahale, kitle imha silahları olmakla suçlanan devletlerin bunlardan arındırılması, rejim değişikliği, demokrasi ihracı gibi gerekçeler müdahale için gerekli kamu desteği sağlanmasında bir araç olarak kullanılmıştır. Hatta Rusya, Çin ve İsrail gibi ülkeler terörle mücadele argümanı şemsiyesi altında ayrılıkçı gruplarla sorunlarını şiddete dökerek çözme yolunu seçmişlerdir (Burchill 2012: 113). Böyle bir ortamda uluslararası toplum, düzen lehine sistemli bir düşünüşün yanı sıra bilhassa gelişmekte olan ülkeler büyük güçlerin kendi iç işlerine karışmalarına firsat verecek bir "Truva atı" haline dönüşmeleri yönündeki endişelerinden dolayı müdahaleyi desteklemekte isteksiz davranmaktadirlar (Evans ve Newnham 2007: 312).

Özetle Soğuk Savaş sonrası dönem, rıza ilkesinin aşındığı ve bu yönde bir rıza arayışına girilmemeye başlandığı bir süreci ifade eder hale gelmiştir. Bunda tarafların rızasını almanın zorluğu da önemli etken olmuştur. Bütün bunlara rağmen rızanın alınması, müdahile daha az sorun yaşatacağı ve müdahaleyi daha ekili kılabileceği söylenebilir. Öyle ki, rızasının alınmaması, çatışan tarafların, üçüncü taraf müdahalelerine ilişkin başta güvensizlik olmak üzere olumsuz algılamalarını tetikleyebilecektir. Bunun ise özellikle müdahil tarafların meşruluğunun tartışıldığı bir ortamda daha belirgin olacağını söylemek mümkündür. 


\section{Uluslararası Örgütlerin Küresel Güçlere Bağımlılığı}

İnşacılar, uluslararası örgütlerin otoriteye sahip olduklarını hatta devletlerin egemenlik alanlarına dahi müdahale edebilen kararlar alabildiklerini öne sürerler (Demirtaş 2014: 118). Bununla birlikte, uluslararas1 müdahalenin, adına müdahale yapılabileceği bir uluslararası toplum varsaydığı göz önüne alındığında uluslararası toplumu yönlendirenlerin güçlü devlet olması, bunların kendi ulusal çıkarlarını uluslararası çıkar olarak meşrulaştırılabilmelerine olanak tanıdığı öne sürülmektedir. Bu argüman güçlü devletlerin farklı gerekçelerle güçsüz devletlere müdahalesinin önünü açan bir proje olarak görülebilmektedir. Devlet şiddetine karşı sivilleri koruma sorumluluğunun uygulanması kadar onun nasıl gerçekleştirildiği de önemlidir. Çünkü müdahaleyi gerçekleştirenlerin kendi adına hareket etmesi de söz konusu olabilmektedir (Balta Paker 2012: 93-94).

Realistlere göre devletlerin en temel işlevleri, güç merkezli olarak tanımlanmış ulusal çıkarlarını gerçekleştirmektir. Çıkarların, devlet tarafından kontrol edilmeyi gerekli kılacak kadar önemli görülmediği hususlarda bürokratik oluşumlar, hükümet dışı veya ulusötesi kurumların bazen devletlerin çeşitli kararlarına aykırı davranabileceğini öne süren realistler, sorunun büyümesi ve buna bağlı olarak çıkarların ciddi şekilde etkilenmesi söz konusu olduğunda devletlerin müdahale ederek kendi politikalarına uygun eylemde bulunacaklarını iddia etmektedirler (Aydın 2004: 41). Bu bakımdan devletlerin niyetleri, kurumları güçlü ya da zayıf yapmaktadır (Waltz 2013: 752). Bundan dolayı, devlet-içi çatışmalar ciddi boyutlara ulaşmadıkça ya da kendi çıkarları doğrudan tehdit altında olmadıkça askeri ve maddi kayıp yaşamamak için bu tür çatışmalara sessiz kalabilmektedirler (Yılmaz 2007: 2). Hatta müdahale etseler de yine bu argümanlar gereği müdahaleden çekilebilmekteler ve müdahaleyi başarısız kılabilmektedirler.

Liberal kurumsalcılara göre uluslararası kurumlar, devletlerin ve sivil toplum kuruluşlarının çıkarlarının açıkça dillendirildiği, görüş birliğinin sağlandığı ve ortak kararların yasallaştırıldığı politik yapılardır (McGrew 2008: 592). Uluslararası kurumların diğer devletler tarafından kolayca kullanılmamaları için göreceli olarak özerk olmaları gerekliliği, özellikle kendi çıkarlarını korumak için bu kurumlara 
daha çok bağlı olan rasyonalist liderler için önemlidir. Bununla birlikte, Keohane'e göre, modern tarihin ayrıntılandırma ve yetkilendirme bakımından en ileri düzeyli çok taraflı kurumu olan AB'nin tarihinde bile, devletlerin kendi ortakları pahasına kendi çıkarlarını elde etme uğruna uluslararası kurumlardan yararlanmayı sürdürdüklerini belirtmektedir (Keohane 2008: 185-186).

Böyle bir ortamda ve geniş çaplı insan hakları ihlallerine karş1 bir şeyler yapma arzusu ile işlerin daha da kötüleştirildiği durumların varlığı beraber ele alındığında müdahalenin başarı karnesinin karma olduğu aşikârdır. Bunda Batılı liderlerin en iyisini kendilerinin bildiğine ve kendi askerileriyle sorunu çözebileceklerine ilişkin inançları etkili olmaktadır. Örneğin, Ruanda'daki soykırımı önlemek amacıyla otoriteyle davranılması ve medeni değerler için hareket edilmesi gerektiğini öngören İngiliz ekolünün tersine burada sorumsuzca davranılmıştır (Booth 2012: 380).

Büyük güçler harekete geçmediklerinde uluslararası toplumun diğer kurumlarının işlevselliği konusunda kuşku duyan Bull (1980), özellikle ABD'yi net bir sonuç almaktan ziyade ruh halini yansıtan politikalarının yerel güç odaklarında caydırıcı etki gösterememesini eleştirmektedir. Uluslararası toplumun tarihini devletler toplumunun temelini oluşturan kültürel uzlaşının zayıflaması ile dekolonizasyon ve yüz yeni devletin kurulmasıyla coğrafi alanın genişlemesi şeklinde tanımlayan Bull, Avrupa'dan dünyanın geri kalanına ihraç edilen uluslararası toplum kurumlarının, güçlerini, bu kurumların devam ettirilmesinde çıkarı bulunan yeni üyelere bağlı olduğunu düşünmektedir. $\mathrm{Bu}$ kurumlara ilişkin yeni bir düzenleme ihtiyacının ise zengin-fakir ayrımı ve ekonomik yeni sömürgecilik algılarının yaygınlaşmasına bağlı olduğunu öne süren Bull, böyle bir ortamda bu kurumlardan en çok fayda sağlayanlarca bu kurumlara zarar verilmesinden korkmaktadir (Aktaran Griffiths, Roach ve Solomon 2011: 217).

Bu bağlamda örneğin 1990'l1 yıllarda BM’nin “düşüşünün” üç önemli nedeni arasında daimi üyelerin rolü ön plana çıkmaktadır: (1) Savaş biçimlerinin değişmesi (iç savaş ve devletler arasındaki çizginin bulanıklaşması), (2) BM'nin başta beş daimi üye olmak üzere üye devletlerce finanse edilmesi ve devletlerin kendi ulusal çıkarlarını BM ça- 
tısı altında gerçekleştirmek istemeleri ve (3) Soğuk Savaş sona erse de, beş daimi üyenin izin verdiği ölçüde işlevsel olabilmesi. Kendi askeri gücü olmayan BM, genel sekreterinin ricası üzerine üye devletlerden bir askeri güç oluşturabilmekte ve bu da hareket kabiliyetini ve büyük güçlerin kendi nüfuz alanlarında etkili olmasını kısıtlayıcı etki doğurmaktadır (Griffiths, O'Callaghan ve Roach 2013: 39).

BMGK daimi üyelerinin konsensüsü sorunu, BM barış güçlerinin başka bir zayıf yönüne işaret eder. Diğer bir deyişle barış güçlerinin etkinliği güçlü devletlerin uyum ve işbirliğine bağlıdır. Soğuk Savaş dönemindeki ideolojik çekişme (ABD bu dönemde 69, Sovyetler Birliği 114 kez veto etmiş) Soğuk Savaş sonrası dönemde göreceli olarak işbirliğine girilerek veto yetkisi sıklıkla kullanılmamaktadır. Ancak devletler üzerinde yaptırım gücüne sahip merkezi bir otoritenin yokluğu sürdüğü sürece veto yetkisi ve işbirliğinden vazgeçme her zaman mümkün olabilmektedir (Y1lmaz 2007: 60-61).

Sayı ve nitelik olarak Soğuk Savaş sonrasında genişleyen BM barış güçlerinin kendi içindeki zayıf yönlerden birisi de nicel ve nitel personel ihtiyacı sorunudur. Doğrudan çıkarı olmayan devlet-içi çatışmalarda pek çok güçlü ülke jandarma görevi üstlenmeye yanaşmamaktadır. Yüksek askeri kapasitesine rağmen ABD ve kendi iç sorunlar1nı öne süren Rusya'nın BM barış güçlerine katkılarının \%1 civarında olması, Japonya'nın personel katkısının olmaması ve AB ülkelerinin $\% 10$ civarında olması kaynakları sınırlı olan ülkelerden bu güçlerin tamamlanması beraberinde kalite sorununu, yani deneyimli ve yeterli uzman sıkıntısını getirmektedir. Bill Clinton döneminden bu yana ABD barış gücü operasyonlarını kendi üzerinde bir yük olarak görme eğilimindedir. 5 Mayıs 1994 tarihli Çok Taraflı Barış Operasyonları Üzerine 25 Nolu Başkanlık Kararı (Presidential Operation Directive 25 on Multilateral Peace Operations, PDD 25) göstermektedir ki ABD bu tür operasyonları yük olarak görmekte ve kendi isteksizliğini meşrulaştırmaya çalışmaktadır. Alınan kararda; ABD çıkarlarını ilgilendirmesi, uluslararası barış ve güvenliğe açık ve ciddi tehdit, amaç ve hedeflerin açıkça belirlenmiş olması, çatışan tarafların rızasının ve ateşkesin olması, operasyonu yürütmede yeterli düzeyde kaynağın olması ve başarı ve sonuçlarına ilişkin gerçekçi kriterlerin bulunmas1 gerekliliği üzerinde durulması bu şartların hepsinin sağlanmasının 
zorluğu bir tarafa, BM Şartı'nın üye ülkelerin ulusal şart koşmaksızın $\mathrm{BM}$ emrine güç göndermesini öngören maddesiyle de çelişmektedir (Y1lmaz 2007: 49-53).

BM'nin etkili çalışmasında, katkı sağlayan başlıca ülke olan ABD ile ilişkileri oldukça önem arz etmektedir. Ancak ICC'nin 1 Temmuz 2002'de kurulmasıyla bu ilişki önemli bir gerilim yaşamıştır. Çünkü $\mathrm{ABD}$ denizaşırı yerlerde $\mathrm{ABD}$ askeri güçlerinin operasyonlarının siyasallaşmış kovuşturma geçirmesinden korktuğu için imzalamaya yanaşmamaktadır. BM ile ABD ilişkilerini etkileyen başka bir gelişme de GWOT ve ABD'nin 2003 Irak işgali olmuştur. Bunlara, BM operasyonları için geniş katılımlı birlik katılımı olasılığını düşürdüğü ve bu işgallerin insani haklılaştırmayı suistimal ettiği gerekçesiyle eleştirel yaklaşılmıştır (Bellamy ve Williams 2013: 137-139).

ABD; Kore (1950), Vietnam (1965) ve Irak'a (1991 ve 2003) müdahalesinde diğer büyük güçlerin baskın bir muhalefetiyle karş1laşmadan müdahale etmede yeterince güçlüydü. Bu tür müdahalelerin tolere edilemez tehditler olduğu için yapıldığg argümanı öne sürülebilse de bu tür bir algılamanın uluslararası sistemden ziyade karar vericilerin algılamalarıyla doğrudan ilişkili olduğu orta çıkmaktadır. $\mathrm{Bu}$ çerçevede neo-klasik realistler yapısal ya da sistemik zorunlulukların çoğu zaman belirsiz olduğunu kavramışlardır (Dueck 2009: 149-150).

ABD’nin bu müdahalelerinde şu tür sonuçlar görülmüştür: Öncelikle iç desteği mobilize etme isteği bakımından başkanın savaşa yönelik özel rasyonalitesi ile onun kamu temsilinde bir boşluk görülmüştür. İkinci olarak, başkanın hareket alanını genişletecek şekilde savaşa yönelik iç siyasi kısıtlamaların oldukça belirsiz ve çok yönlü olduğu görülmüştür. Üçüncü olarak, başkan bu müdahaleleri iç siyasi nedenlerden ziyade yönetimin Amerikan ulusal güvenlik çıkarlarını algıladığ1 şekilde gerçekleştirmiştir. Dördüncü olarak, iç siyasi güdülerin söz konusu müdahaleleri teşviki uluslararası seviyenin altında kalmıştır. Truman Kuzey Kore'ye yönelik geri püskürtme yetkilendirmesinde bulunurken, Johnson Vietnam'daki tırmanmaya ilişkin geçici önlemi tercih ederken, Bush Irak'ta savaş sonrası planlamada başarısız olmuştur. Son olarak, savaşa yönelik popüler desteğin benzer eğilim göster- 
diği, Amerikan askerlerinin müdahaleye başlamasıyla halkın başkanın arkasında toplandığı görülmektedir (Dueck 2009: 166-167).

Askeri gücü, milli siyasetin Clausewitzçi manada saldırgan rasyonel bir aracı olarak kullanmak isteyen devletler, giriştikleri müdahalelerde yasal meşruiyet sorunu yaşarlarsa bu onların şöhretlerine ağır bir darbe indirme potansiyeline sahiptir. Bunun en bariz örneği ABD ve İngiliz liderlerinin 2003'te planladıkları Irak müdahalesi için gerekli onayı BMGK'nden alamamalarında görülmüştür. Bush yönetiminin siyasi şiddetin gayri meşrulaştırılmasına katkıda bulunmada başarısız olduğunu ve siyasi şiddetin meşruiyetinin önleyici savaşla ortadan kaldırılamayacağını öne süren Ken Booth, Irak Savaşı'nın alternatifleri olması sebebiyle gereksiz, Irak askeri gücünün kontrol altına alındığ1 için ihtiyaç olmadığını, BM teftiş sisteminin başarılı görülmesi sebebiyle olumsuz sonuçları yüzünden mantıksız ve BMGK'nin onayı olmadığı için de yasadışı olarak değerlendirmektedir $(2012: 371,511)$.

\section{Maliyet: Bütçe ve Finans Sorunu}

İnsani ihtiyaçların arttığ 1 ve krizin tırmandığ 1 devlet-içi çatışmalarda, müdahillerin harekete geçmesi çok elzem hale gelebilmektedir. Böyle bir duruma müdahalede bulunacak örgüt için karşısına operasyon için maliyetler çıkmaktadır. Gerek operasyona başlama gerekse de operasyonun yeterli sonucu alıncaya kadar etkili bir müdahale gerçekleştirmesi bakımından söz konusu örgütün bunu finanse edebilmesi gerekir. $\mathrm{Bu}$ anlamda müdahalede bulunan örgütlerin kapasitesi ve ek maliyetler yüklendiğinde de üye devletlerin bunu karşılama istekleri ön plana çıkmaktadır. Bu doğrultuda üye devletler insani-çıkar veya her ikisinin de örtüştüğ̈̈ bir tercihte bulunacaklar; bu tercihin müdahalenin selameti ile bağdaşmaması durumunda başarısızlık hiç de uzak ihtimal değildir. Bunun içindir ki insani olabileceği gibi giderleri yansıtan maddi boyutu da yansitabilen maliyetin hangi boyutu yansitırsa yansitsın maliyetin yüksek olması müdahaleyi başarısızlığa sürükleyebilir.

Bütçe ve finans sorunu; güçlü devletlerin kendi üzerlerinde güç kazanarak hegemonyaları için zararlı gördükleri uluslararası örgütleri çıkarlarının gerektirdiği kadar desteklemelerini uygun bulmaları ve bu anlamda maliyetten kaçma anlamında bir isteksizlik sergilemeleriyle de ilintili bir sorundur. Örneğin bu noktada evrensel uluslararası örgüt 
niteliğindeki BM ele alındığında çarpıcı sonuçlar ortaya çıkabilmektedir. Ülkelerin ekonomik kapasiteleri oranında BM bütçesine pay ödemeleri ilkesine rağmen ve yıllık BM barış gücü operasyon maliyetinin 3 milyar Amerikan Dolarından fazla miktar gerektirdiği bir durumda BM'ye en fazla borçlu ülkelerin başında ABD ve Rusya'nın gelmesi manidardır (Yılmaz 2007: 54-55).

1990'larda BM'nin bu operasyonlar için ayırdığı bütçe yarım milyar Amerikan Doları iken, 1997'de 1 milyara, 2007'de 5.5 milyara ulaşmış, 1947-2007 arasında bu yöndeki toplam harcamaların ise 41.74 milyar Dolar olduğu düşünülmektedir (Griffiths, O'Callaghan ve Roach 2013: 30-31). Bu çerçevede müdahalenin maliyetini karşılama noktasında farklı yönelimlere girişilmesi sürpriz olmayacaktır. Örneğin, BM güçleri doğrudan ülkeye gönderilerek müdahaleleri yönetebilirken, bazen üye ülkelere bu hakkı vererek dışardan yönetmeyi yeğleyebilmektedir. Bazen müdahalenin maliyetini uluslararası toplum ile finansal çevreler karşılarken, bazen de yerli halk müdahaleyi üstlenen ülkeye maliyetini gelecekte ödemektedir (Elmi 2012: 221).

2000'den beri BM liderliğinde, baskıları takiben bir dizi reformlar gerçekleştirilmiş ve böylece BM'nin barışı koruma bütçesi içinde ödemelerin dağılımında değiş̧iklik olmuştur. Eski sistemde p-5 (5 daimi üye) gelişmiş, gelişen ve en az gelişmiş şekilde 4 kategoride paylaştırılırken, yeni sistemde A'dan J'ye kadar 10 kategoriye ayrılmış devletler bulunmakta ve bu yeni sistemde p-5 devletleri barışı koruma maliyetlerinin yaklaşık \%2'sini karşılayarak kendilerini rahatlatmış durumdadırlar. Yine Genel Kurul, 5. Komitesi aracılığıyla barışı koruma operasyonlarının finansmanında önemli rol üstlenmektedir (Bellamy ve Williams 2013: 61).

Wilfried Hinsch, müdahale konusunda yapılacak adil bir dağıtım düzenlemesiyle, "istekliler koalisyonunun" kendi maliyetlerini sadece kendilerinin karşıladıkları mevcut durumdan daha fazla tarafa paylaştırabileceğini belirtir (2013: 114). Thomas Pogge ve Walter Pfannkuche (2002) de askeri müdahaleler için gerekli yüksek harcamalara dikkat çekerek, savaşların nedenlerinden biri olan yoksullukla savaşmanın, insan haklarının korunmasına yönelik askeri müdahalelere başvurmaktan daha önemli olduğuna vurgu yaparak sorununun kaynağına inmeye 
çalışmaktadırlar (Aktaran Hinsch 2013: 115). Dünyanın en az gelişmiş kıtası olmasının yanı sıra yoksulluk ve yoksunluğun, insan güvensizliğinin hat safhada olduğu bir coğrafyayı tanımlayan Afrika (Schoeman 2006: 240) göz önüne getirildiğinde bu hiç de yabana atılır cinsten değildir.

\section{Sonuç}

Sömürge geçmişine sahip devletler başta olmak üzere Batılı olmayan ve küresel adaleti düzene tercih edenlerin yanı sıra bizzat çatışan tarafların dış müdahaleye karşı güvensizlikleri ortaya çıkabilmektedir. Siyasi uzlaşı, kaynak eksikliği, komuta, eğitim ve liderlik sorunları gibi yetersizlikten dolayı uluslararası örgütlerin yaşadığı sorunlar vardır. Hatta müdahillerin çatışmayı derinleştirme ihtimali de bulunmaktadır. Ayrıca çatışan tarafların rızasının göz ardı edildiği durumlar güvensizlik başta olmak üzere diğer tür olumsuz algılamalara yöneltebilecek türdendir. Yine uluslararası örgütleri oluşturanların devletler olması ve bunlardan özellikle daimi üyelerinin tutumları bazen müdahaleyi başarısızlığa sürüklerken, bütçe ve finans yönünden maliyetli olan müdahaleler de uluslararası örgüt müdahalelerini başarısız kılabilmektedir.

Bu tür olgular bir arada değerlendirildiğinde uluslararası örgütlerin devlet-içi çatışmalara müdahalesinin başarısız olma nedenlerini; (a) dış müdahalenin güvensizlik yaratması, (b) müdahale eden aktörün yaşadığı sorunlar, (c) müdahalenin sorunu derinleştirme ihtimali, (d) çatışan tarafların rızasının alınmaması, (e) uluslararası örgütlerin küresel güçlere bağımlılığı, (f) maliyet (bütçe ve finans sorunu) şeklindeki değişkenlerle açıklayabilmenin mümkün olduğu görülmektedir. $\mathrm{Bu}$ noktada iki hususa vurgu yapmak gerekir. Bunlardan ilki, bu parametrelerin içeriklerinin kısmen örtüşme gösterebileceği ve dolayısıyla birbiriyle bağlantılı olduklarına ilişkindir. İkincisi ise, uluslararası örgüt müdahalesinin başarısızlığı için illa ki bütün bu şartların bir arada olmasının gerekmediği, bir ya da birkaç faktörün yeterli olabileceğidir.

$\mathrm{Bu}$ parametrelerden ilkini oluşturan dış müdahalenin güvensizlik yaratması; özellikle eleştirel teorisyenler ve yapısalcılar tarafından ele alınan bir konu olduğu ve bu teorisyenlerin müdahaleye kuşku ile yaklaştıkları görülmektedir. Ayrıca başta 'yeni sömürgecilik' söylemi olmak üzere birçok şekilde Üçüncü Dünya Ülkelerinin Batılı devletle- 
rin öncülüğündeki müdahalelere kuşkuyla yaklaştıkları görülmektedir. İkinci olarak, müdahale eden aktörün yaşadığı sorunlarda çok sayıda 'sorunun' varlı̆̆g göze çarpmaktadır. Bunların; örgütlerde veto gücünün bulunması ve konsensüsün sağlanamamasından, bürokratik yapı, ahlaki tutum, eğitim, dil, liderlik, yetki, kaynak, lojistik, strateji ve tecrübe eksikliği ve aksaklıklarına kadar geniş bir yelpazeye yayıldığı görülmektedir.

Üçüncü olarak, müdahaleye karar verenlerin yanlış algılamaları, bilgisiz olmaları, zamanlama yanlışlıkları yapmaları ve yanlış müdahale tipi seçmeleri, siyasi çıkarların insani çıkarlara tercih edilmesi, barış koruyucuların etkisiz olması, hatta yerel şiddetin uygulayıcısı olmaları gibi nedenler müdahalenin sorunu derinleştirme ihtimalini artırmaktadır. Realist argümanlara da çanak tutabilecek şekilde ilgili müdahalenin durumu daha kötüye götürmesini engellemek için ve çözüm sürecinin uzun bir süreci barındırma olasılığı, söz konusu örgüt müdahalesinin uzun soluklu olmasina ve aciliyet arz etmesi durumunda başvurulmasına özen gösterilmesini gerekli kılmaktadır.

Dördüncü olarak, çatışan tarafların rızasının alınmaması; bazen örgüt içindeki büyük devlet çıkarlarının öncelenmesi ve uluslararası sorumluluk şemsiyesi altında gerçek niyetin gizlenmesi gibi eleştirileri beraberinde getirirken, bu tür eleştirilerin egemenlik ilkesinin ve rıza ilkesinin aşınması şeklindeki eleştirilerden bağımsız olmadığını ve hatta onların türevi olduğunu göstermektedir. Beşinci olarak, örgüt içindeki özellikle güçlü devletlerin çıkarları doğrultusunda hareket etmelerinin, özellikle konsensüs ve veto yetkisini barındıran uluslararası örgütlerin etkinliğinde oldukça önemli rol oynadığı görülürken, üye devletlerin çıkarlarıyla çelişmesi halinde mevcut müdahaleden çekilmelerinin de örgütün başarısızlığına doğrudan etki ettiği görülmektedir. Son olarak, gerek asker kaybı gerekse de maddi yönden olsun söz konusu uluslararası örgüt müdahalesinin maliyetli olması, müdahalenin başarısızlığına etki eden bir başka unsur olarak göze çarpmaktadır. 


\section{Kaynakça}

Axelrod, Robert ve Keohane, Robert O. (2013). “Anarşi Koşullarında İşbirliğinin Sağlanması: Stratejiler ve Kurumlar”. Çev. Merve Özkan Borsa. iç. Uluslararası Illişkilerde Anahtar Metinler. Der. Esra Diri. İstanbul: Uluslararası İlişkiler Kütüphanesi. 341-370. Aydın, Mustafa (2004). "Uluslararası İlişkilerin “Gerçekçi” Teorisi: Kökeni, Kapsamı, Kritiği”. Uluslararası Illişkiler. Cilt 1, Sayı 1: 33-60.

Balta Paker, Evren (2012). Küresel Güvenlik Kompleksi: Uluslararas1 Siyaset ve Güvenlik. İstanbul: İletişim Yayınları.

Bellamy, Alex J. ve Williams, Paul D. (2013). Understanding Peacekeeping. Second edition. Cambridge: Polity Press.

Booth, Ken (2012). Dünya Güvenliği Kuramı. Çev. Çağdaş Üngör, İstanbul: Küre Yayınları.

Burchill, Scott (2012). "Liberalizm". Çev. Ali Aslan, iç. Uluslararası Iliş̧kiler Teorileri. İstanbul: Küre Yayınları, 81-118.

Dahl, Robert A. (2008). "Uluslararası Örgütler Demokratik Olabilir Mi? Bir Şüphecinin Görüşü”. Çev. Ezgi Sarıtaş. iç. Küresel Dönüşümler: Büyük Küreselleşme Tartışmalarl. Hzl. David Held ve Anthony McGrew, Ankara: Phoneix, 628-642.

Demirtaş, Birgül (2014). "İnşacılık”. iç. Uluslararası Illişkilere Giriş. 1. Basım. Ed. Şaban Kardaş ve Ali Balcı, İstanbul: Küre Yayınlar1, 110-122.

Deng, Francis M. (2013). "Reconciling Sovereignty with Responsibility: A Basis for International Humanitarian Action". iç. Africa in World Politics: Engaging a Changing Global Order. Ed. John W. Harbeson ve Donald Rothchild, USA (Boulder, CO): Westview Press, 310-349.

Dueck, Colin (2009). "Neoclassical Realism and the National Interest: Presidents, Domestic Politics, and Major Military Interventions". iç. Neoclassical Realism, the State, and Foreign Policy. Ed. Steven E. Lobell, Norrin M. Ripsman ve Jeffrey W. Taliaferro. UK: Cambridge University Press, 139-169.

Elmi, Afyare Abdi (2012). Somali: Kimlik İslami Hareketler ve Barış. İstanbul: Açılım Kitap. 
Evans, Graham ve Newnham, Jeffrey (2007). Uluslararası İlişkiler Sözlüğü. Çev. H. Ahen Utku, İstanbul: Gökkkubbe.

Fortna, Virginia Page. (2007). Does Peacekeeping Work? New Jersey: Princeton University Press.

Franck, Thomas M. (1996). "The Success and Failure of International Organizations", Proceedings of the Annual Meeting (American Society of International Law). Vol. 90, Are International Institutions Doing Their Job?, 596-598.

Gallarotti, Giulio M. (1991). "The Limits of International Organization: Systematic Failure in the Management of International Relations", International Organization. Vol. 45, No. 2, 183-220.

Galtung, Johan (2004a). "Emperyalizmin Yapısal Teorisi”. Uluslararası İlişkiler. Cilt 1, Sayı 2, 25-46.

Galtung, Johan (2004b). "Emperyalizmin Yapısal Teorisi-Kısım II". Uluslararası İlişkiler. Cilt 1, Sayı 3, 37-66.

Griffiths, Martin, O'Callaghan, Terry ve Roach, Steven C. (2013). Uluslararası Ilişsilerde Temel Kavramlar. Çev. CESRAN, Ankara: Nobel Akademik Yayıncılık.

Griffiths, Martin, Roach, Steven C. ve Solomon, M. Scott (2011). Uluslararası İlişkilerde Temel Düşünürler ve Teoriler. Çev. CESRAN, Ankara: Nobel Akademik Yayıncılık.

Habermas, Jurgen (2008). "Ulus Sonrası Konumlanma”. Çev. Mehmet Celil Çelebi. iç. Küresel Dönüşümler: Büyük Küreselleşme Tartışmaları. Hzl. David Held ve Anthony McGrew, Ankara: Phoneix, 643-649.

Hafner-Burton, Emilie M. ve Montgomery, Alexander H. (2005). "Power Positions: International Organizations, Social Networks, and Conflict". Journal of Conflict Resolution. Vol. 20, No. 10, $1-25$.

Halliday, Fred (2008). "Küresel Yönetişim: Beklentiler ve Sorunlar". Çev. Ezgi Sarıtaş. iç. Küresel Dönüşümler: Büyük Küreselleşme Tartışmaları. Hzl. David Held ve Anthony McGrew, Ankara: Phoneix, 578-590.

Hampson, Fen Osler (2001). "Parent, Midwife, or Accidental Executioner? The Role of Third Paties in Ending Violent Conflict". 
iç. Turbulent Peace: The Challenges of Managing International Conflict. Ed. Chester A. Crocker, Fen Osler Hampson ve Pamela Aall, Washington, D.C.: United States Institute of Peace Press, 387-406.

Hashmi, Sohail H. (2003). "Is There an Islamic of Humanitarian Intervention?". iç. Just Intervention. Ed. Anthony F. Lang Jr., USA: Georgetown University Press, 62-83.

Heywood, Andrew (2013). Küresel Siyaset. Çev. Nasuh Uslu ve Haluk Özdemir, Ankara: Adres Yayınları.

Hinsch, Wilfried (2013). "Kant, İnsanc1l Müdahale ve Ahlaksal İstisnacılık”. iç. Barışın Felsefesi: 200. Ölüm Yıldönümünde Kant. Hzl. İoanna Kuçuradi, Ankara: Türkiye Felsefe Kurumu, 85118.

Hoffmann, Stanley (2001). “The Debate about Intervention”. iç. Turbulent Peace: The Challenges of Managing International Conflict. Ed. Chester A. Crocker, Fen Osler Hampson ve Pamela Aall, Washington, D.C.: United States Institute of Peace Press, 273-284.

Jeong, Ho-Won (2008). Understanding Conflict and Conflict Analysis. London: SAGE.

Keohane, Robert O. (2008). "Uluslararası Toplumda Egemenlik". Çev. Cemil Boyraz iç. Küresel Dönüşümler: Büyük Küreselleşme Tartışmaları. Hzl. David Held ve Anthony McGrew, Ankara: Phoneix, 178-195.

Levy, Jack S. (2001). "Theories of Interstate and Intrastate War: A Levels-of-Analysis Approach". iç. Turbulent Peace: The Challenges of Managing International Conflict. Ed. Chester A. Crocker, Fen Osler Hampson ve Pamela Aall, Washington, D.C.: United States Institute of Peace Press, 3-28.

Linklater, Andrew (2012). “İngiliz Okulu”. iç. Uluslararası İlişkiler Teorileri. Çev. Muhammed Ali Ağcan, İstanbul: Küre Yayınları, 119-150.

McGrew, Anthony (2008). "Ulus-Ötesi Demokrasi Modelleri”. Çev. Ezgi Sarıtaş. iç. Küresel Dönüşümler: Büyük Küreselleşme Tartışmaları. Hzl. David Held ve Anthony McGrew, Ankara: Phoneix, 591-608. 
Meyers, B. David (1974 ). "Intraregional Conflict Management by the Organization of African Unity". International Organization. Vol. 28, No. 3, 345-373.

Nakayama, Mikiyasu (1997). "Successes and Failures of International Organizations in Dealing with International Waters", International Journal of Water Resources Development. Vol. 13. No. 3, 367-382.

Newman, Michael (2011). "Humanitarian Intervention and the Responsibility to Protect: Who Should Intervene?". Civil Wars. Vol. 13, No. 3, 339-340.

Olonisakin, Funmi (2006). "Conflict and Conflict Resolution in Africa". iç. Power, Wealth and Global Equity: An International Relations Textbook for Africa. Third edition. Ed. Patrick J. McGowan, Scarlett Cornelissen ve Philip Nel, Cape Town: UCT Press, 265-282.

Özerdem, Alpaslan (2013). Barış İnşası, Kuram ve Uygulaması. Ankara: Nobel Akademik Yayıncılık.

Pogge, Thomas W. (2008). "Küresel Adaletin Öncelikleri”. Çev. Mehmet Celil Çelebi, iç. Küresel Dönüşümler: Büyük Küreselleşme Tartışmaları. Hzl. David Held ve Anthony McGrew, Ankara: Phoneix, 650-662.

Roskin, Michael G., Cord, Robert L., Medeiros, James A. ve Jones, Walter S. (2013). Siyaset Bilimi: Bir Giriş. Çev. Atilla Yayla, Ankara: Adres Yayınları.

Schoeman, Maxi (2006). “Africa's International Relations”. iç. Power, Wealth and Global Equity: An International Relations Textbook for Africa. Third edition. Ed. Patrick J. McGowan, Scarlett Cornelissen ve Philip Nel, Cape Town: UCT Press, 240-264.

Seybolt, Taylor B. (2008). Humanitarian Military Intervention: The Conditions for Success and Failure. Sweden: SIPRI. New York: Oxford University Press.

Smith, Alastair (2005). "Why International Organizations Will Continue to Fail Their Development Goals", Perspectives on Politics. Vol. 3, No. 3, 565-567.

Soutball, Roger (2006). "Africa in the Contemporary World". iç. Power, Wealth and Global Equity: An International Relations Text- 
book for Africa. Third edition. Ed. Patrick J. McGowan, Scarlett Cornelissen ve Philip Nel, Cape Town: UCT Press, 219-239.

Waltz, Kenneth N. (2013). "Soğuk Savaş Sonrasında Yapısal Realizm”. Çev. Papatya Alkan Genca. Uluslararası Illişkilerde Anahtar Metinler. Der. Esra Diri. İstanbul: Uluslararası İlişkiler Kütüphanesi. 733-769.

Y1lmaz, Muzaffer Ercan (2007). Soğuk Savaş Sonrası Dönemde Etnik Çatışmalar: Etnik Çatışmaların Nedenleri ve Etnik Barışın Tesisi. Ankara: Nobel Yayın Dağıtım. 